\title{
White-collar unions and attitudes towards income inequality, redistribution, and state-market relations
}

Article

Accepted Version

Arndt, C. (2018) White-collar unions and attitudes towards income inequality, redistribution, and state-market relations. European Sociological Review, 34 (6). pp. 675-693. ISSN 1468-2672 doi: https://doi.org/10.1093/esr/jcy033 Available at https://centaur.reading.ac.uk/79185/

It is advisable to refer to the publisher's version if you intend to cite from the work. See Guidance on citing.

To link to this article DOI: http://dx.doi.org/10.1093/esr/jcy033

Publisher: Oxford University Press

All outputs in CentAUR are protected by Intellectual Property Rights law, including copyright law. Copyright and IPR is retained by the creators or other copyright holders. Terms and conditions for use of this material are defined in the End User Agreement.

$\underline{\text { www.reading.ac.uk/centaur }}$ 
Central Archive at the University of Reading

Reading's research outputs online 


\section{White-collar unions and attitudes towards income inequality, redistribution, and state-market relations}

\section{Introduction}

The role of trade unions for public policy, public policy outcomes, and political behaviour is a wellstudied topic (e.g. Becher and Pontusson 2011; Kjellberg 2013; Mosimann and Pontusson 2017; Nijhuis 2009; Pontusson 2013). A serious shortcoming in this literature is that unions are usually treated as unitary actors, and differences within the union movement are largely ignored (cf. Becher and Pontusson 2011 for this critique; see also Arndt and Rennwald 2016). This is striking since not least the Scandinavian countries saw the membership growth in independent white-collar unions and their federations at the expense of the traditional blue-collar (and commonly studied) union federations (Kjellberg 2013). For instance, the Swedish blue-collar union federation LO represented three out of four organized wage earners in 1960, while fifty years later, a majority of organized wage earners were represented by the two white-collar federations SACO and TCO (calculations based on Visser 2013). Since these white-collar federations do not represent the traditional bluecollar worker with low to mean income, but usually higher skilled professionals in both the public and private sectors, their growth has important but so far understudied political implications.

First, the traditional assumptions about unions as advocates of redistribution and state intervention do not necessarily hold in the case of independent white-collar federations since this type of union represents potential 'losers' of redistribution and state intervention. If this is true, we can expect, second, that their members do support less redistribution and more market-based allocation of incomes as well as privatization. Third, given the changing composition of the union movement, public policies that lead to more inequality and more-market based provision of goods and services might face less resistance or even gain support among many union members as 
potential beneficiaries. To overcome the lack of studies on the political implications of the divided nature of union movements, the paper investigates the relation between union fragmentation and political preferences in Scandinavia since the 1980s.

Some recent contributions have already begun to inspect how the variation within the union movement and the decline of blue-collar membership affects political preferences but have only used union density or the income scale represented by unions as a measure (or proxy) for union fragmentation (e.g. Becher and Pontusson 2011; Mosimann and Pontusson 2017; Pontusson 2013; Vlandas 2016; but see Kim and Margalit 2016). Other studies have looked at voting patterns across members' different union federations without tapping into the mechanism that links a white-collar union member to a conservative party for instance (Arndt and Rennwald 2016).

To contribute to this debate, I therefore analyse the attitudes towards redistribution and statemarket relations in Denmark, Norway, and Sweden across union federation membership in the last three decades. These three countries witnessed a considerable growth in white-collar union membership at the expense of traditional union federations and thus resemble crucial cases to study the attitudinal differences between members of encompassing unions and the members of independent white-collar federations. Using national election surveys and opinion surveys distinguishing union membership by federation at the individual level, this study addresses an important gap in the literature on union membership and political preferences. Thereby, it shows that using simple dummies for union membership can cause substantial aggregation bias.

The remainder of this article is structured as follows. First, I summarize the existing literature on white-collar unions and attitudes towards state-market relations to deduce my theoretical expectations on the attitudes of white-collar union members towards (income) inequality, privatization, and state-market relationships. Afterwards, I present the case selection, data, and measurement. Then, I use fixed effects OLS-regressions to distinguish the political attitudes of 
white-collar union members from the traditional blue-collar union members and to tap into income solidarity across unions. The final section discusses the findings.

\section{Theoretical expectations on white-collar union membership and political preferences}

While the academic study of unionism and union membership fills libraries, white-collar unionism has often been neglected or seen as a subordinate issue in the political science and sociology literature. ${ }^{1}$ Max Weber's classical work (1922: 177ff) distinguished positively privileged occupational groups within the middle class (positiv privilegierte Erwerbsklasse) from other types of employees and workers. These classes contain civil servants, liberal professions, and workers, who are able to monopolize their skills and secure better life chances. Privileged occupational classes can first monopolize entrepreneurial management for the sake of its members and their business interests, and second safeguard those interests through influence on the economic policy of the political and other organizations (Weber 1922: 178). Lederer (1912) further distinguished whitecollar associations from blue-collar unions in terms of the preferences for social closure of middle class professions to conserve differences in income and status. By implication, these classes can easier foster collective action and achieve their goals if these are promoted by separate professional unions even though Weber did not address the issue of white-collar federations explicitly.

Later, some British studies of the 1960s and 1970s engaged in mainly theoretically motivated discussions on the conceptualization of white-collar unionism and as to whether white-collar unions have similar goals as the traditional blue-collar unions within the TUC or represent other forms of interest representation and political strategies (Blackburn and Prandy 1965; Crompton 1976; Lockwood 1966). Particularly, the debate centred around the issue of whether white-collar unions represent a distinct class of wage earners in the strict sense (the sociological approach) or only represent the interests of their members in the same company or branch when it comes to payment 
or job security (the industrial relations approach, cf. Crompton 1976 for a summary of this debate). Pelling (1971) found that separate craft unions in Britain were historically strong opponents of wage compression. In this regard, Esping-Andersen and Korpi (1984) argued that in countries where white-collar unions and interest organisations could secure their political influence, social policy remained segmented across occupational lines and privileges for white-collar employees and civil servants in welfare coverage remained intact.

Later studies inspected the preference formation within the different union movements. Nijhuis (2009) argued that the union structure matters for preference formation and the unions' preference for welfare policies. If unions organize high- and low-skilled workers within the same federation, then the unions will take a more solidaristic stance towards welfare arrangements and redistribution. In contrast, if high-skilled workers (and thus higher incomes) have their own federations separated from low-skilled workers, then these federations will take less solidaristic positions since their members will be losers of redistribution, and the organizational differentiation from the low-income colleagues prevents the formation of the underlying support for redistribution (see Nijhuis 2009, esp. 301-306). While Nijhuis (2009) and others (e.g. Ruysseveldt and Visser 1996: 228; Swenson 1989) have pointed to the importance of separate federations and union fragmentation for political preference formation, many studies from the power resources theory assumed that 'unions in different countries represent essentially the same, more or less homogeneous, constituency' (see Becher and Pontusson 2011: 186 for this rightful critique). This was also labelled as an equivalence premise by Swenson (2002: 8).

In this respect, various empirical contributions that encompassing unions that represent a very large share of the labour force and income scale do lead to more positive towards redistribution and state intervention (Olsen, 1965; Becher and Pontusson 2011; Mosimann and Pontusson 2017; Nijhuis 2009; Pontusson 2013; Vlandas 2016; see also Arndt and Rennwald 2016 for a similar 
argument on party choice of union members). One key argument is that unions uniting low and high incomes under the same umbrella produce stronger solidaristic attitudes than unions that only represent distinct groups of wage earners or qualifications (Olson 1982; also refers to the solidarity effect in Pontusson's words). The latter is particularly the case with some Scandinavian union federations that predominantly represent academics and professionals (e.g. AC/Lederne in Denmark, AF in Norway, or SACO in Sweden). The results show that encompassing unions are associated with less inequality and lower wage dispersion at the macro-level. Moreover, members of encompassing unions with high incomes are more supportive of redistribution than non-members with similar incomes. While the studies by Pontusson and others provide valuable theoretical insights, they use macro-variables on union structures and income representation, treat unions as homogeneous macro-level actors, or only use union membership dummies at the micro-level and do not disentangle membership in different federations (a data limitation mentioned in Becher and Pontusson 2011: 184). This would be a direct proof of the claim that unionized well-paid wage earners are more sceptical about redistribution.

Nevertheless, we can deduce that if unions only represent distinct skills and/or income groups that (mostly) lie above the mean income, then solidaristic attitudes will be weaker, and there will be more positive attitudes towards markets and inequality. In this respect, Becher and Pontusson (2011: 184) discuss the possibility that low-skilled workers with below-average incomes actually do not or no longer represent a majority of union members. This issue should matter particularly if these high-income union members are organized in separate federations that mainly represent these interests. Consequently, these union members would gain from lower taxes and more market-based employment relations if we apply Meltzer and Richard's (1981) argument to redistributive preferences among union members of different federations. In other words, they would be losers of redistribution. 
This should be reinforced at the organisational level because unions act as collective actors that need to take into account the preferences of their members to formulate their objectives, values, and goals. Unions with a rather broad membership base across various classes and income groups (encompassing unions) take more inclusive (or solidaristic) stances to reflect the average or median member's preferences, but should also internalize the costs of their policies, e.g. compensating losers of redistribution with selected benefits or privileges (Olson 1982: 48ff, 90ff).

In contrast, unions with a more narrow membership base defined through crafts, occupation or occupational sector have different objectives because they represent members who would benefit from externalizing the costs of privatisation or larger wage gaps if occupational unions promote wage growth for middle class professions (Nijhuis 2009). These unions will, for instance, not advocate or even fight too much risk-pooling or redistribution through taxes to avoid that the wage increases for their members will be diluted and will likely communicate this to their members, who hold these or adopt their preferences. Given the narrower representational domains of white-collar unions, even collective identities supporting union action and membership may be particularistic and therefore promote solidarity among a close and possibly quite limited group of wage-earners.

This means that both the organisational objectives, values, and goals and the reasons supporting union membership are not similar between these two types of unions. While I do not assume that the organisational goals and the ideology of particularistic white-collar unions are perfect determinants of their members' preferences, I expect that they do account for diverging preferences between members of encompassing and members of particularistic unions.

Since, in contrast to unified union federations, separate independent federations do not foster the sense of solidarity postulated in Mosimann and Pontusson (2017), we can expect their members to be more positive towards market allocation and less supportive of redistribution than members of encompassing federations (H1). This is reinforced through spatial (at the plant level) and 
organizational separation as there is no joint union congress in which high-income and high-skilled members are in contact with colleagues from the lower income scale. This produces a less distinct feeling of solidarity and drives a stronger and narrower representation of white-collar workers' own interests.

Another variant of this argument comes from Hassel's (2014) study of union strategies and labour market dualism in Germany since the Agenda 2010 reforms. Unions representing higher income labour might welcome more market-based income policies as the purchasing power of their members increases if wages in the private low-pay service sectors are primarily determined by market forces and not by collective or corporatist agreements. This would particularly include privatization or marketization of low-skilled services that were offered by the public sector before (e.g. postal service or transport). This might be muted to some degree since a considerable share of white-collar union members work in the middle-ranking civil service, who would be the losers of an outright marketization that includes privatization of their work and services as well. In this respect, we can expect that independent white-collar unions are at least moderately supportive of privatization and more sceptical about state control/ownership compared to members of traditional blue-collar federations $(\mathrm{H} 2)$. Accordingly, the support for privatization should be weaker in those white-collar federations dominated by public sector employees. Moreover, and given the different income segments represented by the respective federations, we can also in a broader sense expect that members of white-collar and independent unions harbour more pro-market attitudes compared to the members of blue-collar unions who should harbour pro-state attitudes (H3).

In the following, I test these three hypotheses with data on socio-economic preferences among Scandinavian union members that allow a distinction between the type of federation (traditional blue-collar, white-collar, and private sector white-collar). 


\section{Case selection, data, and measurement}

The Scandinavian countries provide crucial cases to study the link between trade union membership and attitudes towards redistribution and state-market relationships (see Gerring 2007, esp. 115ff). These countries still had high union density rates in international comparison by 2010 (Denmark: 69, Norway: 55, Sweden 69 per cent, based on Visser 2013), but fundamentally different union structures compared to the heydays of industrialization. This is important for testing my hypotheses as the encompassing union federations (LO) had lost ground since the 1970s, while occupational federations with narrower representational domains have increased their membership share continuously.

On that score, Figure 1 demonstrates that all three countries have fragmented trade union landscapes, where not one but three umbrella organizations have existed: one for blue-collar workers (LO in all three countries), one for white-collar employees mainly in the public sector (FTF in Denmark, UNIO in Norway, and TCO in Sweden), ${ }^{2}$ and one for academics and private-sector professionals (AC/Lederne in Denmark, AF in Norway, and SACO in Sweden). Traditionally, LO was the dominating union federation as it organized 75-80 per cent of all union members by 1960 (see Figure 1).

\section{FIGURE 1 ABOUT HERE}

Since 1960, LO has witnessed a relative membership decline as the share organized by LO has fallen to around 50 per cent in Denmark and Norway and even below 50 per cent in Sweden by 2010. In contrast, the share of white-collar unions has risen since 1980 . By 2010, the public whitecollar federations organized every fifth union member in Denmark and Norway and every third in Sweden. Similarly, the academic and private-sector federations represent at least 10 per cent of all 
members after the turn of the millennium, while they had a very marginal position in the 1960 s. In Denmark and Norway, independent federations such as YS also play a role, while they were insignificant in Sweden throughout the whole period. ${ }^{3}$ In sum, the traditional blue-collar union federations have lost significant importance in Scandinavia, while white-collar federations organize larger and larger parts of the workforce. Consequently, these three countries provide crucial cases for testing my hypotheses that white-collar union members are less solidaristic and more marketoriented. With Scandinavians generally being in favour of egalitarian wage structures (e.g. Finseeras 2009; Jæger 2006), the expected differences between different types of union members should be detectable here or nowhere. Furthermore, if there are similar patterns in all three countries, we can rule out that the Ghent system is a main explanation since it is applied in Denmark and Sweden, but not in Norway. The Danish and Swedish Ghent systems imply that even wage-earners with high incomes need to join a union if they want to be covered by the unemployment insurance (and further benefits), while these wage-earners in Norway can opt out given the public unemployment insurance as in Continental Europe. Finding similar results for the independent union federations in Norway would therefore substantiate that the Ghent system is not a driving force for my findings. This is the rationale for using Norway and contrast it with the two other countries.

I use the Danish National Election Studies (1979-2011), the Norwegian Election Studies (1981-2013), and the annual Swedish Riks-SOM surveys (1986-2010) to inspect my hypotheses (see appendices for details). The reason for choosing these data is straightforward: They are the only surveys that consistently contain both a detailed variable on union federation membership and various questions on attitudes towards redistribution, wage inequality, state intervention, and privatization that have been asked on a regular basis over time. This also allows for constructing a state-market index to capture the overall position of union members on socio-economic issues. This 
overcomes data limitations of existing studies that only examine macro-relationships (e.g. income scale represented by unions and social spending) or rely on dummies on union membership (no/yes) when inspecting political preferences (e.g. Mosimann and Pontusson 2017). In this respect, I provide a direct test of white-collar unionism on attitudes towards socio-economic issues at the individual level. One serious shortcoming of pooled cross-sectional data is that they do not allow strict tests for self-selection into unions according to political predispositions and thus the presence of endogeneity. Accordingly, the analysis does not provide causal inference in a strict sense, and I have addressed this issue with various sensitivity tests using matching, extra controls and instrumental variables that antecede the respondents' choice of a union in the appendix, Tables A6A8 (see Kim \& Margalit 2016 for a similar procedure).

The main independent variable of interest is union federation membership, where I distinguish between non-members, LO-members, white-collar public federation members (FTF, UNIO, and TCO), and members of academic private-sector federations (AF/Lederne, AF, and SACO). I further report results for the Norwegian YS, a larger non-affiliated federation, when relevant. The dependent variables are attitudes on inequality/wage differentials, privatization/state intervention in the private economy, and a country-specific state-market scale based on those items that have been consistently used in the respective countries.

The item on inequality/wage differentials was phrased as follows:

\section{Denmark}

A says: 'The differences in incomes and living standards are still too large in this country. Therefore, people with lower incomes should have a quicker improve in their living standards than people with higher incomes'. 
B says: "Redistribution of incomes has gone far enough. The differences in incomes found nowadays should by and large be maintained.

(1 Agree with A, 2 Agree with B, 3 Agree with neither A nor B)

\section{Norway}

We have some more statements. We will continue to use the answer alternatives: strongly agree, agree somewhat, disagree somewhat, and strongly disagree. Would you please tell me which of the answers you choose for each statement I read to you?

'To exhort people to greater effort, we should be willing to accept greater differences in wage levels'.

(1 Strongly agree, 2 Agree somewhat, 3 Yes and no, 4 Disagree somewhat, 5 Strongly disagree)

\section{Sweden}

Below, you find some proposals from the political debate. What is your opinion on them?

'Reduce income inequality in society?' (phrasing in 1986, 1987, 1988, 2011, 2012), respectively, ‘Accept larger wage differences' (phrasing in 1998, 1999, 2001) (recoded into five-point scales from 1 'in favour of less inequality' to 5 'in favour of more inequality').

The item on privatization/state intervention in the economy was phrased as follows:

\section{Denmark}


'The state does not have enough control over private investments'.

(1 Agree completely, 2 Agree partly, 3 Neither/nor, 4 Disagree partly, 5 Disagree completely)

\section{Norway}

'Would you please tell me which of the answers you choose for each statement I read you?'

We should allow commercial private schools. (1 Strongly agree, 2 Agree somewhat, 3 Yes and no, 4 Disagree somewhat, 5 Strongly disagree, rescaled so that Strongly agree got 5)

In case the private school item was missing, I used a similar item on health care privatization as measure for attitudes towards privatization

'Then comes the question of whether to allow private health care services on a commercial basis in addition to the public health care.' (10 point scale rescaled into scale from 1 totally disagree to 5 totally agree)

\section{Sweden}

'What is your opinion on the following proposal: Denationalize public companies such as Telia' (asked 1987-2000). 'What is your opinion on the following proposal: Sell public companies that have regular business activities' (asked 2007-2010).

(1 Very good proposal, 2 Good proposal, 3 Neither/nor, 4 Bad proposal, 5 Very bad proposal)

All of the items mentioned have been rescaled to a five-point scale, where 1 denotes the most pro-state answer and 5 the most pro-market answer. 
The state-market scale for each country was constructed based on those items that have consistently been used in the respective studies (see Table 1). In those years where a given item was missing, I replaced it with an item that had a similar meaning, if possible (for details, see Tables A1a-A1c in the online appendix). ${ }^{4}$ This also means that the items vary between countries to some degree, but they all cover attitudes towards state intervention and market allocation since the scales yield acceptable to good reliability scores (Cronbach's alpha) and always yield one-factorial solutions (not shown). Hence, despite their not identical item formulation, I regard them as comparable measures of attitudes towards state intervention within the three countries that allow me testing my third hypothesis. The state-market scale is an additive index for each country that goes from 0 'totally in favour of state intervention' to 100 'totally in favour of market allocation' and consists of the items shown in Table 1.

\section{TABLE 1 ABOUT HERE}

\section{Analysis}

To demonstrate that the different federations do indeed represent different social strata, Table 2 presents some important social characteristics of Scandinavian union members across the different federations for the last survey year available and compares them with the average voter as well as non-members.

\section{TABLE 2 ABOUT HERE}

Table 2 reveals the average income, the share of highly educated as well as the share of public sector employees over union federation membership. In all three countries, the members of the 
white-collar federations (FTF, AC, UNIO, AF, TCO, and SACO) earn on average more than the LO members and the mean voter. Moreover, LO members earn less than the mean voter as well as nonmembers in Norway and Sweden, while there is no significant income difference between LO members and the mean voter in Denmark. With respect to education, we can see that all whitecollar federations have a disproportionally high share of members with high education, whereas the LO has a below-average share of highly educated members. This difference is most pronounced in Norway. Last, all unions organize more public sector employees than private sector employees, but the difference between public and private is least pronounced for the LO in all three countries. A notable cross-national difference occurs among the 'academic' unions, where the Danish $\mathrm{AC} /$ Lederne is dominated by members from the private sector, whereas public employees are more common in the Norwegian AF and the Swedish SACO. Nevertheless, the picture found in this table is clear: White-collar unions in Scandinavia organize people with incomes clearly above the mean and also above the average income of their LO colleagues, they organize predominantly highly educated voters, and they organize members from the sheltered public sectors. This confirms the underlying premises of my arguments on white-collar unions above. Consequently, we should expect that their interests with regard to redistribution and state-market relationships should differ from union members in encompassing unions that organize members across all income groups and educational backgrounds (such as the Austrian ÖGB). The next step of the analysis is therefore to inspect the attitudes towards redistribution, privatization, and state intervention among members of the different federations.

\section{TABLE 3 ABOUT HERE}

Table 3 presents the relationship between union federation membership and attitudes towards redistribution in the three countries. The models are fixed effects OLS-regressions with three 
specifications, one base model with only union membership, age, sex and residence as controls and two further specifications with education, income, private/public sector occupation, and class as controls to demonstrate that union federation membership is partly mediated through these factors, but that it also has independent explanatory power. The coefficients in the baseline models M1 show that the members of independent federations (public and private) do favour less redistribution compared to LO members (reference category) in all three countries. The coefficient for the academic professional unions is the strongest and also stronger than the coefficient for nonmembers signalling that this type of union member does accept larger wage differences and thus inequality. The coefficient for the public sector unions in Denmark and Sweden vanishes if more demographic controls are added, but we still see highly significant coefficients for the academic/professional unions even if we control for education, income, sector or social class. Albeit the coefficients in M2 and M3 are reduced compared to M1, the controls do not account for all inter-union differences in attitudes towards redistribution. Members of all three academic/professional union federations do support higher wage differentials compared to LO members, and the differences are statistically significant at least at $p<.01$ in all specifications. This means that we would produce a serious aggregation bias when merging all union members into one category and contrast them with non-members. The members of the white-collar public sector unions in Norway and Sweden and the independent Norwegian YS fall in between the academic and LO members, but still harbour less egalitarian attitudes than LO members. ${ }^{5}$ Accordingly, the analysis in Table 3 provides strong support for my first hypothesis that members of independent white-collar federations are more positive towards market allocation and less supportive of redistribution than ordinary LO members. This also goes against some of the classical assumptions positing that all union members hold egalitarian attitudes. Next, I examine my second hypothesis that the members of white-collar unions are also supportive of privatization and marketization. 


\section{TABLE 4 ABOUT HERE}

Table 4 presents a similar series of regression models with the respective attitudes towards privatization and marketization among members of the different federations as dependent variable. The pattern is clearer in Denmark and Sweden, where AC and SACO members significantly support less state involvement and more privatization of public-owned companies compared to LO members. The coefficients reduce when adding more controls in M2 and M3, but stay highly significant in all specifications. In Norway, the coefficient for AF membership is modest, but similar and significantly positive (at least at $\mathrm{p}<.05$ ) in all three models. The coefficients for the public sector federations FTF and TCO in Denmark and Sweden are similar but weaker compared to the academic federations, while the coefficient for Norwegian public sector federation UNIO remains insignificant. In contrast, we can see that members of the independent YS in Norway are strongly supportive of privatization (in this case schools and health). This supports my expectation that preferences for privatization are weaker in the independent public sector organizations compared to the academic/professional and usually private sector federations.

Further significance tests show that only non-members and YS differ from LO members, while the confidence intervals of AF and UNIO strongly overlap with the one for LO (see Table A1 in the appendix). One likely explanation is that the Norwegian independent federations do organize a higher degree of public sector employees than their counterparts from Denmark and Sweden (see Table 1). In sum, the evidence for Denmark and Sweden clearly confirms my second hypothesis that white-collar union members are at least moderately supportive of privatization and oppose state 
control/ownership compared to members of traditional blue-collar federations. For Norway, the most distinct results occur for YS, while the differences between AF and LO are weaker.

\section{TABLE 5 ABOUT HERE}

Finally, the models in Table 5 inspect the positions of union members across federations on the broader state-market index to test H3. Except for the TCO in Model 3 for Sweden, we can observe that all coefficients for the independent federations are significantly positive across all specifications, which means that these union members are generally more in favour of market allocation compared to their LO-colleagues. Given the scale from 0-100, one can say that members of academic federations are 4.3 to 7.4 per cent more "right-wing" on the state-market scale than LO members even if we control for education, income, private/public sector occupation, and class in the fixed effect OLS specification in Model 3. This confirms my third hypothesis.

To further inspect the role of socio-demographic background variables and to deal at least tentatively with potential self-selection of professions into union federations, Figure 2 visualizes the coefficients for union membership on the state-market scale from the full models in Model 3 from Table 5 and compared them with the differences in means (t-tests) of the different federations on the state-market scale (see Table A1 for the t-tests and see Figure A2 from the online appendix for a similar analysis with the redistribution items). The graphs compare the coefficients for union membership in white-collar federations with those of non-members using LO as reference category. The full models yield the coefficients for union membership across federations controlled for a variety of demographic factors and how they diverge from the differences in means. First, all whitecollar unions are consistently to the right of LO in all specifications which confirms my third hypothesis. This means that the more inegalitarian attitudes of AC/AF/SACO members are partly explained through their occupation, income or education, but they do not vanish fully since there is 
always a statistically significant difference to their LO fellows, which suggests that self-selection cannot explain the whole difference to LO-members in these cases.

\section{FIGURE 2 ABOUT HERE}

Moreover, for the contrast with non-members, we can see that Danish AC members are more right-wing than non-members, that Norwegian AF members are as right-wing as non-members, and that Swedish SACO members are slightly more left-wing than non-members when looking at the differences in means. These differences to non-members vanish in Denmark and Norway in the full models, and stay the same in Sweden. The non-difference to non-members in the full models for Denmark and Norway means that members of academic federations are at least as liberal or rightwing as non-members when controlling for their demographic background.

Another interesting finding occurs for the comparison of the means and full models for the public sector unions (FTF, UNIO, and TCO). These union members are more right-wing than LO members, but more left-wing than non-members and members of academic unions when looking at the differences in means. The difference to LO either becomes insignificant (Sweden) or comes close to insignificance (Denmark and Norway) when adding the full set of control variables. This indicates that a certain share of the attitudinal differences between the public sector and the LO unions are explained through demographic factors or even self-selection, the latter being nondetectable with the cross-sectional data in hand.

These results therefore suggest that unions that only represent higher income scales and not a broader composition of wage earners have members who do not necessarily support egalitarian 
policies and state intervention, as many classical theories and previous empirical analyses assume (see Becher and Pontusson 2011: 186 for the respective critique). In contrast, they can have members that have quite pro-market standpoints on socio-economic issues as they benefit from market allocation of incomes.

\section{Compression of attitudes among income scale}

To further investigate the role of union federation across income groups and tap into conditional solidarity, I ran a regression model consisting of an interaction between union federation membership and income and several controls (education, public sector employment, age, and sex) as independent variables and the state-market relationship scale as dependent variable. ${ }^{6}$ The income variable is measured as income quintiles in all three countries based on the respective household income variables for each survey. The income quintiles capture the income distribution among all wage-earners and not within the unions only. The results are presented as predicted values on the state-market scale across union federation membership and income groups in Figure 3 to facilitate interpretation. The underlying regression coefficients appear in Table A5 in the Appendix. Figure 3 shows that LO membership is associated with more 'left-wing' attitudes on the state-market scale among higher income groups (fourth and fifth quintiles) compared to members of the academic and public sector federations. The differences between LO members from the fourth and fifth income quintile and members of the academic federations from the fourth and fifth quintile are significant at $\mathrm{p}<.05$ in all three countries. Moreover, we find significant differences between UNIO/TCO members and LO members among the two upper income quintiles in Norway and Sweden. In Denmark, the difference between LO and FTF is significant for the fourth but not the fifth income quintile. Additionally, we find similar statistically significant differences in the fourth and fifth income quintiles for LO versus members of the independent federations (especially YS in Norway). 
Consequently, white-collar employees with higher incomes have a weaker sense of solidarity and show less support for state intervention when organized in independent federations than well-paid members organized in encompassing federations. This also becomes visible when we look at the differences between the five income quintiles within each federation. The differences between the fifth/fourth and second/first quintiles are larger for the academic and public sector federations than for LO.

\section{FIGURE 3 ABOUT HERE}

These differences are more pronounced in Norway and Sweden, where there are almost no attitudinal differences between the income groups for LO, but a strong spread of opinions over income groups for UNIO, AF, TCO, and SACO. The fact that we find similar results for Norway and Sweden means that the Ghent system cannot be a main explanation given the absence of the Ghent system in Norway. In Denmark, the income differences within each federation are not that persistent, while we do observe more right-wing opinions for the more well-off groups in FTF and AC compared to LO $^{7}$ These patterns can be replicated by models containing instruments for potential self-selection and by comparing the differences in predicted values across union federations and income group for an otherwise similar white-collar employee (see appendix Tables A6-A8).

In sum, traditional and encompassing blue-collar unions can compress the attitudes of different income groups and have members with stronger support for state intervention. The opposite pattern is true for independent white-collar federations, where the well-paid members are more in favour of market allocation and less solidaristic with their low-paid colleagues within the same federation. There is less compression of attitudes across income quintiles in independent 
white-collar federations as in case of the encompassing federations. This confirms my general argument that the different income segments represented by the respective federations imply promarket attitudes among the independent federations compared to the members of blue-collar unions who harbour pro-state attitudes. ${ }^{8}$

In a broader sense, this analysis provides the micro-foundation of Becher and Pontusson's (2011) claim that unionization by income matters for attitudes towards redistribution state intervention. Unions that predominantly represent higher incomes - and thus the opposite of what Olson and Pontusson labeled as encompassing unions - have members that are less in favour of redistribution and also larger attitudinal differences between income groups.

An obvious caveat of this study is whether and to which degree we can generalize the results to contexts outside Scandinavia. Wage-earners who are members of the academic federations in Scandinavia might likely be non-members in Continental Europe given the absence of larger academic or white-collar federations. This would mean that the results found for the academic federations in this study would be mirrored by similar attitudes for academics and professionals who remain unorganized in Continental Europe - which would suggest that the independent academic federations do not shape distinctive attitudes of their members and are just a functional equivalent of non-membership in other contexts. The case of Norway speaks against this potential objection since AF members were clearly more right-wing than LO members (and non-members in some cases), while the country has no Ghent-system and higher class professionals could opt out of unions as they do in many other European countries. A brief comparison with Austrian and German data in the online appendix confirms these patterns.

This supplementary analysis for Austria and Germany supports the results found for the three Scandinavian cases. The comparison of the differences in means on social inequality (Figure B2 in supplementary analysis) shows that the patterns for independent white-collar unions in Sweden and 
Germany are somewhat similar. Members of the SACO in Sweden and the German independent federations DBB/ULA are the most inegalitarian union members and also to the right of nonmembers on redistribution. This indicates that the results for the independent white-collar federations in Scandinavia are not deviating substantially in their attitudes towards inequality from other white-collar unions in Continental Europe. The supplementary analysis in Figure B1 in the online appendix demonstrates that members of the ULA and DBB are consistently more right-wing than DGB members and also at least as right-wing as non-members on three selected items. This pattern reflects my results for Scandinavia from Tables 3 to 5 above. Running similar interaction models for Austria with income quintiles across union membership as in Figure 3 above (see Figures B3 and B4 in the online appendix) demonstrates that the encompassing ÖGB has a similar compression of attitudes along the income scale as the Swedish LO, while the independent Swedish federations have a much larger spread of preferences across the income scale than LO or ÖGB members.

\section{Conclusion}

The purpose of this article was to overcome a serious limitation in the literature on union membership and political attitudes: the assumption that union members usually favour state intervention and egalitarian policies. So far, many analyses of union membership and political behaviour have not accounted for trade union fragmentation and the rise of independent federations that predominantly organize well-educated and higher paid professionals in the private and public sectors. Instead, union membership was operationalized as a dichotomy (yes/no), or macrovariables on the income scale represented by unions were used (Becher and Pontusson 2011; Mosimann and Pontusson 2017; Vlandas 2016). My basic argument was that if high-skilled workers (and thus higher incomes) have their own federations separated from low-skilled workers, these 
federations will take less solidaristic positions since their members will be losers of redistribution, and the organizational differentiation from the low-income colleagues prevents the formation of the underlying support for redistribution (see also Nijhuis 2009 on this point). This article used union federation membership in Scandinavia at the micro-level to inspect whether members of independent white-collar federations have the same attitudes as members of the encompassing federations.

My results suggest that members of white-collar federations are more in favour of market allocation of incomes and less redistribution, they support privatization at least to a moderate degree, and they are generally more sceptical about state intervention than members of traditional blue-collar federations. Furthermore, the effect of income on having more 'right-wing' attitudes on the state-market dimension is reinforced by membership in an independent white-collar federation because this type of federation does not compress the attitudinal differences of the highest and lowest income quintiles, as some recent analysis would suggest (Mosimann and Pontusson 2017). These findings have some implications for the political economy of unionism as well as future studies of the effect of union membership on political attitudes and behaviour.

First, the analysis contributes to understanding when and under which circumstances we find pro-state or pro-market attitudes among union members. The recent analysis by Mosimann and Pontusson (2017) has shown that encompassing unions (i.e. coverage of large parts on the income strata) and high union density increases the effect of union membership on support for redistribution, and they also found that this effect is strongest among high-wage workers. In this respect, my analysis adds that this assumption only holds if the members are organized within the classical type of union - the traditional encompassing blue-collar union with ties to the labour movement and social democracy. As soon as independent unions organize the segment of welleducated and high-wage workers separately, we find less solidarity among these union members 
and in fact, we find more support for market allocation of incomes than for wage compression. Similarly, this analysis provides a micro-foundation for the recent findings from Arndt and Rennwald (2016) as to why white-collar union members vote conservative and not social democratic. Accordingly, the present study addresses one vital point made by Becher and Pontusson (2011), namely, that we should take into account unionization by income when investigating the stances of union members on socio-economic issues. This means that we should make analytical distinctions between the types of union that organize particular income groups. Bearing in mind problems with self-selection, the analysis above provides a first but still more direct test of the arguments on unionisation by income, respectively, the effect of encompassing unionism on the attitudes of high-wage workers.

This brings me to my second implication pointing to the problem of aggregation bias. Future studies that aim at investigating the role of union membership on inequality, solidarity perceptions, and political behaviour should differentiate between union federation membership on the microlevel to disentangle the effects of traditional unionism and other forms of unionism. This concerns particularly the presence of independent federations that do not correspond to the concept of encompassing unions - even though high union density rates at the macro-level might suggest that a given country (e.g. Sweden) has encompassing unions covering all income groups. Consequently, using dummies on union membership might in the worst case yield misleading conclusions or nonfindings caused by aggregation of completely different groups of union members (Simpson's paradox).

Third, if unions increasingly represent the higher income strata and upper white-collar middle class, we can expect that the willingness to accept more inequality and more market-based provision of goods and services among union members will ceteris paribus rise. This might of course be a composition effect since the electorate eventually consists of more high-income union 
members in white-collar federations than blue-collar workers. This process then pushes the attitudinal balance in favour of more market-based arrangements even though high union density rates will prevail in the Scandinavian context. Nevertheless, there might also be a context effect that accelerates this development further since Arndt and Rennwald (2016) found that the effect of white-collar union membership on voting for conservative parties increased with the share of members organized in this type of federation.

Similarly, the problem of self-selection into the white-collar federations needs to be investigated more closely since the present design with pooled cross-sectional data has its obvious limitations to causal inference here. Still, even with self-selection, we obtain biased results if we capture members of different union federations only through one dummy. These are definitely issues for further investigation and calls for a systematic comparison of Scandinavia with Continental Europe on that matter with data of high quality at the micro- and macro-level.

\section{References}

Arndt, C. and Rennwald, L. (2016). 'Union members at the polls in diverse trade union landscapes'. European Journal of Political Research, 55(4): 702-22.

Becher, M. and Pontusson, J. (2011). 'Whose interests do unions represent? Unionization by income in Western Europe'. In Research in the Sociology of Work, vol. 22B, edited by David Brady. London: Emerald Press, 181-211.

Blackburn, R. M. and Prandy, K. (1965). 'White-collar unionization: A conceptual framework'. The British Journal of Sociology, 16(2): 111-122.

Crompton, R. (1976). 'Approaches to the study of white-collar unionism'. Sociology, 10 (3): 40726. 
Esping-Andersen, G. and Korpi, W. (1984): Social Policy as Class Politics in Post-War Capitalism: Scandinavia, Austria, and Germany. In Order and Conflict in Contemporary Capitalism, edited by John H. Goldthorpe. Oxford: Clarendon, 179-208.

Finseeras, H. (2009). 'Income inequality and demand for redistribution'. Scandinavian Political Studies, 32(1): 94-119.

Gerring, J. (2007). Case Study Research. Principles and Practices. Cambridge, Cambridge University Press.

Hassel, A. (2014). 'The paradox of liberalization - understanding dualism and the recovery of the German political economy’. British Journal of Industrial Relations, 52(1): 57-81.

Ibsen, C. L., Due, J. and Madsen, J. S. (2015). 'Fald i organisationsgrad... igen, igen'. FAOS Employment Relations Research Centre, University of Copenhagen.

Jæger, M. M. (2006). 'Welfare regimes and attitudes towards redistribution: The regime hypothesis revisited'. European Sociological Review, 22(2): 157-70.

Kim, S. E. and Margalit, Y. (2016). 'Informed preferences? The impact of unions on workers' policy views'. American Journal of Political Science, 61(3): 728-743.

Kjellberg, A. (2013). 'Union density and specialist/professional unions in Sweden'. Research Report 2013:2 (updated 2014). Lund: Studies in Social Policy, Industrial Relations, Working Life and Mobility, Lund University.

Lederer, E. (1912). Die Privatangestellten in der modernen Wirtschaftsordnung. Tübingen, Mohr \& Siebeck.

Lockwood, D. (1966). The Blackcoated Worker. London, Allen and Unwin.

Meltzer, A. and Richard, S. (1981). 'A rational theory of the size of government'. Journal of Political Economy 89 (5): 914-27. 
Mosimann, N. and Pontusson, J. (2017). 'Solidaristic Unionism and Support for Redistribution in Contemporary Europe. World Politics 69 (3): 448-492.

Nijhuis, D. O. (2009). 'Revisiting the role of labor worker solidarity, employer opposition, and the development of old-age pensions in the Netherlands and the United Kingdom'. World Politics, 61 (2): 296-329.

Olson, M. (1965). The Logic of Collective Action. Cambridge MA: Harvard University Press. Olson, M. (1982). The Rise and Decline of Nations. Economic Growth, Stagflation, and Social Rigidities. New Haven: Yale University Press.

Pelling, H. (1971). A History of British Trade Unionism. London: Macmillan Pontusson, J. (2013). 'Unionization, inequality and redistribution'. British Journal of Industrial Relations, 51 (4): 797-825.

Ruysseveldt, J. van and Visser, J. (1996). Industrial Relations in Europe: Traditions and Transitions. London: Sage.

Scheuer, S. (2006). 'Klar svækkelse af den faglige organizering de sidste ti år i Danmark'. Notat, Roskilde University Centre.

Statistisk Årbog (various years). Copenhagen, Danmarks Statistik.

Swenson, P. (1989). Fair Shares. Ithaca: Cornell University Press.

Swenson, P. (2002). Capitalists against Markets. Oxford, Oxford University Press.

Visser, J. (2013). 'Data base on institutional characteristics of trade unions, wage setting, state intervention and social pacts, 1960-2011 (ICTWSS), Version 4.0'. Amsterdam: Amsterdam Institute for Advanced Labour Studies, University of Amsterdam. Available online at: www.uva-aias.net/208.

Vlandas, T. (2016). 'Coordination, inclusiveness and wage inequality between median- and bottomincome workers'. Comparative European Politics. doi:10.1057/cep.2016.25. 
Weber, M. (1922). Wirtschaft und Gesellschaft (Grundriß der Sozialökonomik; Abt. 3). Tübingen, Mohr \& Siebeck.

Weibull, L., Holmberg, S., Oscarsson, H., Martinsson, J., and Markstedt, E. (2014). Super-RiksSOM 1986-2012, v2014.1.2. Göteborgs Universitet: SOM-institutet, www.som.gu.se.

\section{Notes}

${ }^{1}$ This of course relates to the limitation in many surveys that only operationalize union membership as a dummy (yes/no), prohibiting any further serious investigation into this aspect of unionism.

${ }^{2}$ I will use the abbreviation AF for the two union federations that mainly represent academic professions in Norway. Until the mid1990s, Akademikernes Fellesorganisasjon represented this segment, while after a split, Akademikerne was formed in 1997 as a federation for academic professions, while UNIO was formed as a mainly public sector white-collar federation in 2001. This means that I treat AF as a joint white-collar federation until 1997 and then distinguish between UNIO as a 'new' federation and Akademikerne as a natural successor of the original AF.

${ }^{3}$ In Denmark and Norway, some unions left the academic federations and became non-affiliated (e.g. Ingeniørforeningen in Denmark) or joined another (e.g. Norske Sivilingeniørers Forening left AF and joined UNIO). Some also rejoined other federations later. This problem is beyond the scope of this article.

${ }^{4}$ One example: The Swedish Riks-SOM's privatization was usually phrased as follows: 'What is your opinion on the following proposals: Denationalize public companies such as Telia'. In later studies, the same introduction was used, and the wording was the following: 'Sell public companies that have regular business activities'. I regard this difference in wording as tolerable since both clearly tap into privatization of public companies in Sweden and used the second item in case the regular item was not included in given survey.

${ }^{5}$ Similar results occur for alternative measurements of attitudes towards economic inequality in Denmark and Norway (available on request from author).

${ }^{6}$ I also added fixed effects for survey years to control for unobserved heterogeneity and year-specific developments that might have affected public attitudes such as economic crisis, government composition, and the membership share of the different union federations over time.

${ }^{7}$ One likely cause is the smaller income gap between LO and the other federations in Denmark compared to Norway and Sweden (see Table 2).

${ }^{8}$ A robustness check with an interaction containing public/private sector*union federation corroborates this. Members of independent federation working in the private sector are more economically liberal compared to private sector employees organized by LO in all three countries. See Figure A3 in online appendix. 


\section{Tables and figures}

Table 1: Overview of items used for construction of state-market scale

\begin{tabular}{lll}
\hline Country & Items used for index & $\begin{array}{l}\text { Cronbachs alpha, } \\
\text { standardized }\end{array}$ \\
\hline Denmark & $\begin{array}{l}\text { 1) Increase taxes on higher incomes, 2) Redistribution of incomes has } \\
\text { gone far enough, 3) More state control over private investments, 4) } \\
\text { Private businesses should decide over their own matters, 5) Equal living } \\
\text { standard irrespective of occupation and education, 6) Social reforms have } \\
\text { gone too far }\end{array}$ & 0.6827 \\
& $\begin{array}{l}\text { 1) Higher incomes to be taxed harder (in some years abolish wealth tax), } \\
\text { Norway }\end{array}$ & 0.6616 \\
& $\begin{array}{l}\text { 2) Greater differences in wage levels, 3) Reduce state control of private } \\
\text { industry, 4) Expansion of public sector more important than tax cuts, 5) }\end{array}$ & \\
Reduce income differences, 6) Allow private schools/health service & \\
Sweden & $\begin{array}{l}\text { Proposals: 1) Cut taxes, 2) Reduce size of public sector, 3) Privatization } \\
\text { of public companies (two wordings used), 4) Support private health care, }\end{array}$ & $\begin{array}{l}\text { 0.7954 (with standard } \\
\text { privatization item) }\end{array}$ \\
& 5) Support private elderly care & $\begin{array}{l}0.7431 \text { (with alternative } \\
\text { privatization item) }\end{array}$
\end{tabular}

Note: See online appendix for details on question wording for items not explained above and missing items in given years. 
Table 2: Social characteristics of union members in Scandinavia across federations by 2010

\begin{tabular}{|c|c|c|c|c|c|}
\hline \multirow{2}{*}{$\begin{array}{l}\text { Social } \\
\text { characteristics }\end{array}$} & \multicolumn{5}{|c|}{ Members across federations } \\
\hline & Non-member & $\mathrm{LO}$ & FTF & AC/Lederne & Average voter \\
\hline $\begin{array}{l}\text { Mean annual } \\
\text { income on scale } \\
2011(\mathrm{~N}=1,686)\end{array}$ & $\begin{array}{l}6.42 * * \\
(\operatorname{mode}=150.000- \\
199.999 \text { DKK })\end{array}$ & $\begin{array}{l}8.24 \\
(\text { mode }=500.000- \\
599.999 \text { DKK })\end{array}$ & $\begin{array}{l}9.74 * * \\
(\operatorname{mode}=600.000- \\
699.999 \mathrm{DKK})\end{array}$ & $\begin{array}{l}10.18^{* *} \\
(\operatorname{mode}=800.000- \\
899.999 \mathrm{DKK})\end{array}$ & $\begin{array}{l}7.93 \\
(\text { mode }=600.000- \\
699.999 \mathrm{DKK})\end{array}$ \\
\hline $\begin{array}{l}\text { Proportion } \\
\text { highly educated } \\
(\mathrm{N}=1,860)\end{array}$ & 36.21 & 25.66 & 67.51 & 71.80 & 40.64 \\
\hline $\begin{array}{l}\text { Proportion } \\
\text { public sector } \\
(\mathrm{N}=1,656)\end{array}$ & 24.92 & 41.86 & 67.65 & 35.63 & 35.98 \\
\hline \multicolumn{2}{|c|}{$\begin{array}{l}\text { Membership share in all members } \\
\text { Union Density }\end{array}$} & $58 \%$ & $18 \%$ & $11 \%$ & $71.5 \%$ \\
\hline Norway & Non-member & LO & UNIO & $\mathrm{AF}$ & Average voter \\
\hline $\begin{array}{l}\text { Mean annual } \\
\text { income } 2013 \\
(\mathrm{~N}=1,471)\end{array}$ & $697.506 \mathrm{NRK}$ & 659.186 NRK & 842.204 NRK** & $959.594 \mathrm{NRK}^{* * *}$ & 722.124 NRK! \\
\hline $\begin{array}{l}\text { Proportion } \\
\text { highly educated } \\
(\mathrm{N}=1,668)\end{array}$ & 30.6 & 21.5 & 93.4 & 95.9 & 37.5 \\
\hline $\begin{array}{l}\text { Proportion } \\
\text { public sector } \\
(\mathrm{N}=1,440)\end{array}$ & 24.7 & 52.1 & 89.9 & 67.4 & 40.7 \\
\hline \multicolumn{2}{|c|}{$\begin{array}{l}\text { Membership share in all members } \\
\text { Union Density }\end{array}$} & $52.5 \%$ & $17.8 \%$ & $9.3 \%$ & $\begin{array}{l}13 \%(\mathrm{YS}) \\
54.8 \%\end{array}$ \\
\hline Sweden & Non-member & LO & $\mathrm{TCO}$ & SACO & Average voter \\
\hline $\begin{array}{l}\text { Mean annual } \\
\text { income on scale } \\
2008 \\
(\mathrm{~N}=10,118)\end{array}$ & $\begin{array}{l}4.47 \\
(\operatorname{mode}=201.000- \\
300.000 \mathrm{SEK})\end{array}$ & $\begin{array}{l}4.38 \\
(\text { mode }=201.000- \\
300.000 \mathrm{SEK})\end{array}$ & $\begin{array}{l}5.55^{* *} \\
(\operatorname{mode}=501.000- \\
600.000 \mathrm{SEK})\end{array}$ & $\begin{array}{l}6.37^{* *} \\
(\text { mode }> \\
800.000 \mathrm{SEK})\end{array}$ & $\begin{array}{l}4.89 * * \\
(\operatorname{mode}=301.000- \\
400.000 \mathrm{SEK})\end{array}$ \\
\hline $\begin{array}{l}\text { Proportion } \\
\text { highly educated } \\
(\mathrm{N}=4,567)\end{array}$ & 29.3 & 7.6 & 49.8 & 93.2 & 35.4 \\
\hline $\begin{array}{l}\text { Proportion } \\
\text { public sector } \\
(4,186)\end{array}$ & 31.2 & 44.5 & 51.8 & 61.0 & 41.4 \\
\hline \multicolumn{2}{|c|}{$\begin{array}{l}\text { Membership share in all members } \\
\text { Union Density }\end{array}$} & $44.1 \%$ & $34.4 \%$ & $17.8 \%$ & $68.9 \%$ \\
\hline
\end{tabular}

Source: Own calculations based on Visser (2013); Danish National Election Study 2011; Norwegian Election Study 2013; Swedish Riks-SOM Study 2008-2010; data for Denmark and Norway are weighted, Swedish drawn on CPR numbers. The Danish and Swedish studies use income scales, while the Norwegian studies asked for the actual household income in Norwegian kroner. See descriptions in the main text and Appendix for details of measurement. The significance tests for income indicate whether the union members have a significantly different household income than the LO members. ! p.<10,* p.<05,** p<.01. 
Figure 1: Composition of trade union memberships across federations in Scandinavia 1960-2010
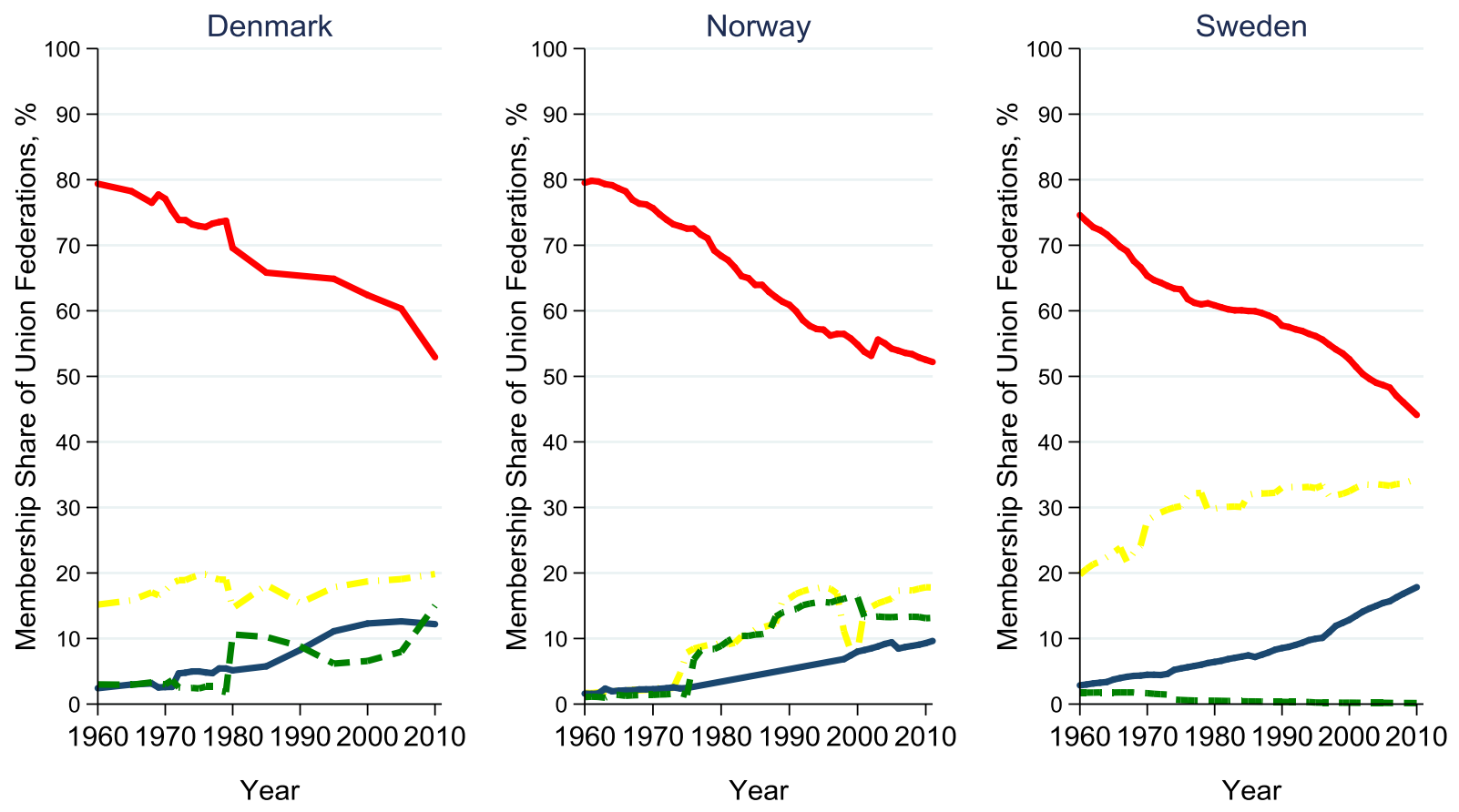

Union Federation

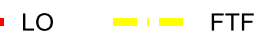

Union Federation

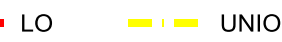

Union Federation

$\mathrm{AC} / \mathrm{LH}=-\mathbf{E}$ Other

AF/Akad. = - YS

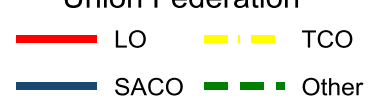

Source: Own calculations based on Statistisk Årbog (various years), Scheuer (2006) and Ibsen et al. (2015) for Denmark, and Visser (2013) for Norway and Sweden. 
Table 3: Attitudes towards redistribution among union members of different federations in Scandinavia

\begin{tabular}{|c|c|c|c|c|c|c|c|c|c|}
\hline & \multicolumn{3}{|c|}{ Denmark } & \multicolumn{3}{|c|}{ Norway } & \multicolumn{3}{|c|}{ Sweden } \\
\hline & M1 & M2 & M3 & M1 & M2 & M3 & M1 & M2 & M3 \\
\hline \multicolumn{10}{|c|}{ Union federation (Ref: $L O$ ) } \\
\hline Non-member & $\begin{array}{c}0.297 * * * \\
(0.023)\end{array}$ & $\begin{array}{c}0.330 * * * \\
(0.031)\end{array}$ & $\begin{array}{c}0.264 * * * \\
(0.033)\end{array}$ & $\begin{array}{c}0.344 * * * \\
(0.027)\end{array}$ & $\begin{array}{c}0.309 * * * \\
(0.028)\end{array}$ & $\begin{array}{c}0.268 * * * \\
(0.034)\end{array}$ & $\begin{array}{c}0.535 * * * \\
(0.028)\end{array}$ & $\begin{array}{c}0.544 * * * \\
(0.033)\end{array}$ & $\begin{array}{c}0.407 * * * \\
(0.039)\end{array}$ \\
\hline Public sector & $0.129 * *$ & 0.086 & 0.068 & $0.409 * * *$ & $0.215^{* *}$ & $0.321 * * *$ & $0.425 * * *$ & $0.222 * * *$ & 0.065 \\
\hline$(F T F, U N I O, T C O)$ & $(0.040)$ & $(0.061)$ & $(0.061)$ & $(0.066)$ & $(0.068)$ & $(0.093)$ & $(0.031)$ & $(0.037)$ & $(0.046)$ \\
\hline Private/academic & $0.335 * * *$ & $0.237 * * *$ & $0.175^{* *}$ & $0.554 * * *$ & $0.311 * * *$ & $0.271 * * *$ & $0.854 * * *$ & $0.541 * * *$ & $0.411 * * *$ \\
\hline$(A C, A F, S A C O)$ & $(0.044)$ & $(0.064)$ & $(0.065)$ & $(0.051)$ & $(0.054)$ & $(0.062)$ & $(0.048)$ & $(0.059)$ & $(0.065)$ \\
\hline Other ( $Y S$ in Norway) & $\begin{array}{c}0.253 * * * \\
(0.034)\end{array}$ & $\begin{array}{c}0.184 * * * \\
(0.042)\end{array}$ & $\begin{array}{c}0.150 * * * \\
(0.042)\end{array}$ & $\begin{array}{c}0.296 * * * \\
(0.039)\end{array}$ & $\begin{array}{c}0.181 * * * \\
(0.039)\end{array}$ & $\begin{array}{l}0.106^{*} \\
(0.047)\end{array}$ & $\begin{array}{c}0.323 * * * \\
(0.057)\end{array}$ & $\begin{array}{c}0.252 * * * \\
(0.060)\end{array}$ & $\begin{array}{c}0.170 * * \\
(0.063)\end{array}$ \\
\hline Constant & $\begin{array}{c}1.667 * * * \\
(0.052)\end{array}$ & $\begin{array}{c}1.235^{* * *} * \\
(0.075)\end{array}$ & $\begin{array}{c}1.554 * * * \\
(0.096)\end{array}$ & $\begin{array}{c}2.941 * * * \\
(0.066)\end{array}$ & $\begin{array}{c}1.958 * * * \\
(0.100)\end{array}$ & $\begin{array}{c}2.179 * * * \\
(0.129)\end{array}$ & $\begin{array}{c}2.212 * * * \\
(0.055)\end{array}$ & $\begin{array}{c}1.532 * * * \\
(0.080)\end{array}$ & $\begin{array}{c}1.947 * * * \\
(0.105)\end{array}$ \\
\hline Observations & 10,678 & 6,567 & 6,563 & 15,415 & 15,355 & 11,777 & 10,301 & 7,465 & 7,159 \\
\hline R-squared & 0.036 & 0.062 & 0.072 & 0.071 & 0.091 & 0.095 & 0.086 & 0.128 & 0.144 \\
\hline BIC' & -229.60 & -224.15 & -251.96 & -943.28 & -1229.37 & -927.41 & -755.89 & -827.68 & -866.56 \\
\hline RMSE & 0.941 & 0.930 & 0.925 & 1.369 & 1.354 & 1.372 & 1.129 & 1.090 & 1.083 \\
\hline
\end{tabular}

Sources: Valgundersøgelsen 1979, 1984-2011 for Denmark, Valgundersøkelsen 1981-2013 for Norway, Super Riks-SOM 1986-2010 for Sweden. Notes: Robust standard errors in parentheses, $* * * p<0.001, * * \mathrm{p}<0.01, * \mathrm{p}<0.05,+\mathrm{p}<0.1 ; \mathrm{M} 1$ : union federation dummies and age, residence, sex and fixed effects for years; M2: with income quintiles, private sector occupation and education as further controls; M3 with class as further control in addition to controls from M2. Full models with all controls appear in online appendix. 
Table 4: Attitudes towards privatization among union members of different federations in Scandinavia

\begin{tabular}{|c|c|c|c|c|c|c|c|c|c|}
\hline & \multicolumn{3}{|c|}{ Denmark } & \multicolumn{3}{|c|}{ Norway } & \multicolumn{3}{|c|}{ Sweden } \\
\hline & M1 & M2 & M3 & M1 & M2 & M3 & M1 & M2 & M3 \\
\hline \multicolumn{10}{|c|}{ Union federation (Ref: $L O$ ) } \\
\hline Non-member & $\begin{array}{c}0.302 * * * \\
(0.027)\end{array}$ & $\begin{array}{c}0.397 * * * \\
(0.041)\end{array}$ & $\begin{array}{c}0.308 * * * \\
(0.043)\end{array}$ & $\begin{array}{c}0.552 * * * \\
(0.031)\end{array}$ & $\begin{array}{c}0.474 * * * \\
(0.033)\end{array}$ & $\begin{array}{c}0.465^{* * *} \\
(0.038)\end{array}$ & $\begin{array}{c}0.499 * * * * \\
(0.020)\end{array}$ & $\begin{array}{c}0.496 * * * \\
(0.023)\end{array}$ & $\begin{array}{c}0.382 * * * \\
(0.026)\end{array}$ \\
\hline Public sector & $0.274 * * *$ & $0.200 * *$ & $0.157 *$ & 0.051 & 0.087 & 0.063 & $0.311 * * *$ & $0.182 * * *$ & $0.085 * *$ \\
\hline$(F T F, U N I O, T C O)$ & $(0.042)$ & $(0.064)$ & $(0.064)$ & $(0.068)$ & $(0.070)$ & $(0.088)$ & $(0.023)$ & $(0.027)$ & $(0.032)$ \\
\hline Private/academic & $0.450 * * *$ & $0.317 * * *$ & $0.254 * * *$ & $0.163 * *$ & $0.167 * *$ & $0.180 *$ & $0.442 * * *$ & $0.316 * * *$ & $0.217 * * *$ \\
\hline$(A C, A F, S A C O)$ & $(0.048)$ & $(0.070)$ & $(0.071)$ & $(0.062)$ & $(0.065)$ & $(0.074)$ & $(0.031)$ & $(0.038)$ & $(0.042)$ \\
\hline Other ( $Y S$ in Norway) & $\begin{array}{c}0.231 * * * \\
(0.037)\end{array}$ & $\begin{array}{c}0.198 * * * * \\
(0.049)\end{array}$ & $\begin{array}{c}0.145 * * \\
(0.049)\end{array}$ & $\begin{array}{c}0.351 * * * \\
(0.045)\end{array}$ & $\begin{array}{c}0.324 * * * \\
(0.046)\end{array}$ & $\begin{array}{c}0.299 * * * \\
(0.055)\end{array}$ & $\begin{array}{c}0.385^{* * * *} \\
(0.051)\end{array}$ & $\begin{array}{c}0.309 * * * \\
(0.053)\end{array}$ & $\begin{array}{r}0.228 * * * \\
(0.055)\end{array}$ \\
\hline Constant & $\begin{array}{c}2.358 * * * \\
(0.071)\end{array}$ & $\begin{array}{c}1.773 * * * \\
(0.100)\end{array}$ & $\begin{array}{c}2.383 * * * \\
(0.128)\end{array}$ & $\begin{array}{c}3.029 * * * \\
(0.061)\end{array}$ & $\begin{array}{c}2.683 * * * \\
(0.106)\end{array}$ & $\begin{array}{c}2.933 * * * \\
(0.139)\end{array}$ & $\begin{array}{c}3.057 * * * \\
(0.046)\end{array}$ & $\begin{array}{c}2.636 * * * \\
(0.064)\end{array}$ & $\begin{array}{c}3.095 * * * \\
(0.080)\end{array}$ \\
\hline Observations & 11,592 & 6,883 & 6,877 & 13,655 & 13,611 & 10,122 & 21,986 & 17,883 & 17,158 \\
\hline R-squared & 0.052 & 0.096 & 0.106 & 0.051 & 0.062 & 0.072 & 0.069 & 0.103 & 0.114 \\
\hline $\mathrm{BIC}^{\prime}$ & -454.87 & -495.14 & -523.25 & -532.10 & -639.05 & -516.81 & -1313.05 & -1651.75 & -1718.10 \\
\hline RMSE & 1.177 & 1.215 & 1.209 & 1.467 & 1.459 & 1.446 & 1.208 & 1.183 & 1.177 \\
\hline
\end{tabular}

Sources: Valgundersøgelsen 1979-2011 for Denmark (1994 is excluded), Valgunders $\varnothing$ kelsen 1981-2013 for Norway (1997 is excluded), Super RiksSOM 1986-2010 for Sweden. Notes: Robust standard errors in parentheses, *** $\mathrm{p}<0.001$, ** $\mathrm{p}<0.01, * \mathrm{p}<0.05,+\mathrm{p}<0.1$; M1: union federation dummies and age, residence, sex and fixed effects for years; M2: with income quintiles, private sector occupation and education as further controls; M3 with class as further control in addition to controls from M2. Full models with all controls appear in online appendix. 


\section{Table 5: Position on state-market scale among union members of different federations in Scandinavia}

\begin{tabular}{|c|c|c|c|c|c|c|c|c|c|}
\hline & \multicolumn{3}{|c|}{ "Denmark } & \multicolumn{3}{|c|}{ Norway } & \multicolumn{3}{|c|}{ Sweden } \\
\hline & M1 & M2 & M3 & M1 & M2 & M3 & M1 & M2 & M3 \\
\hline \multicolumn{10}{|c|}{ Union federation (Ref: $L O$ ) } \\
\hline Non-member & $\begin{array}{c}9.724 * * * \\
(0.556)\end{array}$ & $\begin{array}{c}11.842 * * * \\
(0.806)\end{array}$ & $\begin{array}{c}9.295 * * * \\
(0.844)\end{array}$ & $\begin{array}{c}10.870 * * * \\
(0.414)\end{array}$ & $\begin{array}{c}9.618 * * * \\
(0.437)\end{array}$ & $\begin{array}{c}8.975 * * * \\
(0.511)\end{array}$ & $\begin{array}{c}12.485 * * * \\
(0.303)\end{array}$ & $\begin{array}{c}12.046^{* * * *} \\
(0.345)\end{array}$ & $\begin{array}{c}9.316^{* * * *} \\
(0.393)\end{array}$ \\
\hline Public sector & $6.458 * * *$ & $5.685^{* * *}$ & $4.482 * *$ & $4.424 * * *$ & $2.965 * *$ & $3.000^{*}$ & $4.790 * * *$ & $2.241 * * *$ & 0.192 \\
\hline$(F T F, U N I O, T C O)$ & $(0.922)$ & $(1.389)$ & $(1.390)$ & $(1.063)$ & $(1.089)$ & $(1.427)$ & $(0.352)$ & $(0.393)$ & $(0.478)$ \\
\hline Private/academic & $12.936 * * *$ & $9.517 * * *$ & $7.358 * * *$ & $9.364 * * *$ & $7.014 * * *$ & $6.856 * * *$ & $9.274 * * *$ & $6.794 * * *$ & $4.314 * * *$ \\
\hline$(A C, A F, S A C O)$ & $(1.050)$ & $(1.489)$ & $(1.514)$ & $(0.897)$ & $(0.934)$ & $(1.038)$ & $(0.490)$ & $(0.587)$ & $(0.645)$ \\
\hline Other ( $Y S$ in Norway) & $7.393 * * *$ & $5.684 * * *$ & $4.212 * * *$ & $6.896^{* * *}$ & $5.405 * * *$ & $4.743 * * *$ & $9.355^{* * *}$ & $7.670 * * *$ & $5.229 * * *$ \\
\hline & $(0.769)$ & $(0.986)$ & $(0.986)$ & $(0.618)$ & $(0.623)$ & $(0.730)$ & $(0.604)$ & $(0.635)$ & $(0.672)$ \\
\hline Constant & $\begin{array}{c}36.705 * * * \\
(1.471)\end{array}$ & $\begin{array}{c}19.172 * * * \\
(1.968)\end{array}$ & $\begin{array}{c}34.571 * * * \\
(2.505)\end{array}$ & $\begin{array}{c}50.838 * * * \\
(0.981)\end{array}$ & $\begin{array}{c}34.679 * * * \\
(1.598)\end{array}$ & $\begin{array}{c}39.514 * * * \\
(2.038)\end{array}$ & $\begin{array}{c}44.823 * * * \\
(0.831)\end{array}$ & $\begin{array}{c}37.055^{* * * *} \\
(1.061)\end{array}$ & $\begin{array}{c}48.163 * * * \\
(1.271)\end{array}$ \\
\hline Observations & 10,838 & 6,396 & 6,393 & 13,853 & 13,802 & 10,591 & 34,481 & 28,792 & 27,431 \\
\hline R-squared & 0.062 & 0.139 & 0.157 & 0.114 & 0.146 & 0.159 & 0.091 & 0.131 & 0.143 \\
\hline BIC' & -523.24 & -756.25 & -844.90 & -1480.99 & -1938.07 & -1586.85 & -2949.27 & -3682.46 & -3808.93 \\
\hline RMSE & 23.29 & 23.23 & 23.00 & 20.78 & 20.39 & 20.18 & 22.65 & 22.14 & 21.98 \\
\hline
\end{tabular}

Sources: Valgundersøgelsen 1979-2011 for Denmark (1994 is excluded), Valgundersøkelsen 1981-2013 for Norway, Super Riks-SOM 1986-2010 for Sweden. Notes: Robust standard errors in parentheses, $* * * p<0.001, * * p<0.01, * p<0.05,+p<0.1$; M1: union federation dummies and age, residence, sex and fixed effects for years; M2: with income quintiles, private sector occupation and education as further controls; M3 with class as further control in addition to controls from M2. 
Figure 2: Comparison of means on state-market scale and coefficients for union membership from full models (M3 in Table 5 )

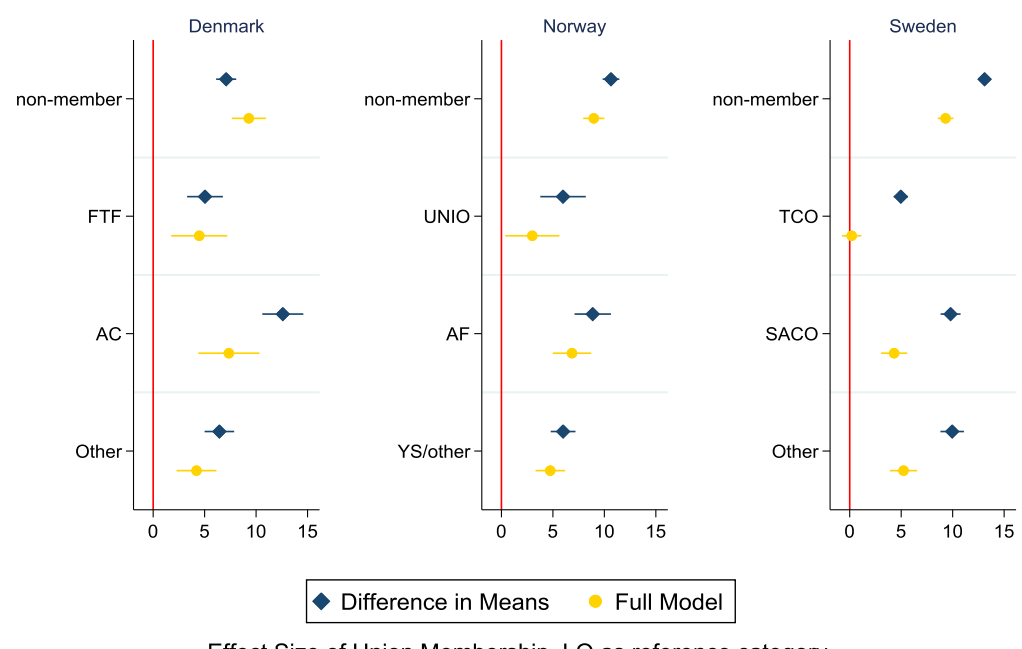

Effect Size of Union Membership, LO as reference category 
Figure 3: Positions on the state-market scale across income groups and union federation membership in Denmark, Norway, and Sweden

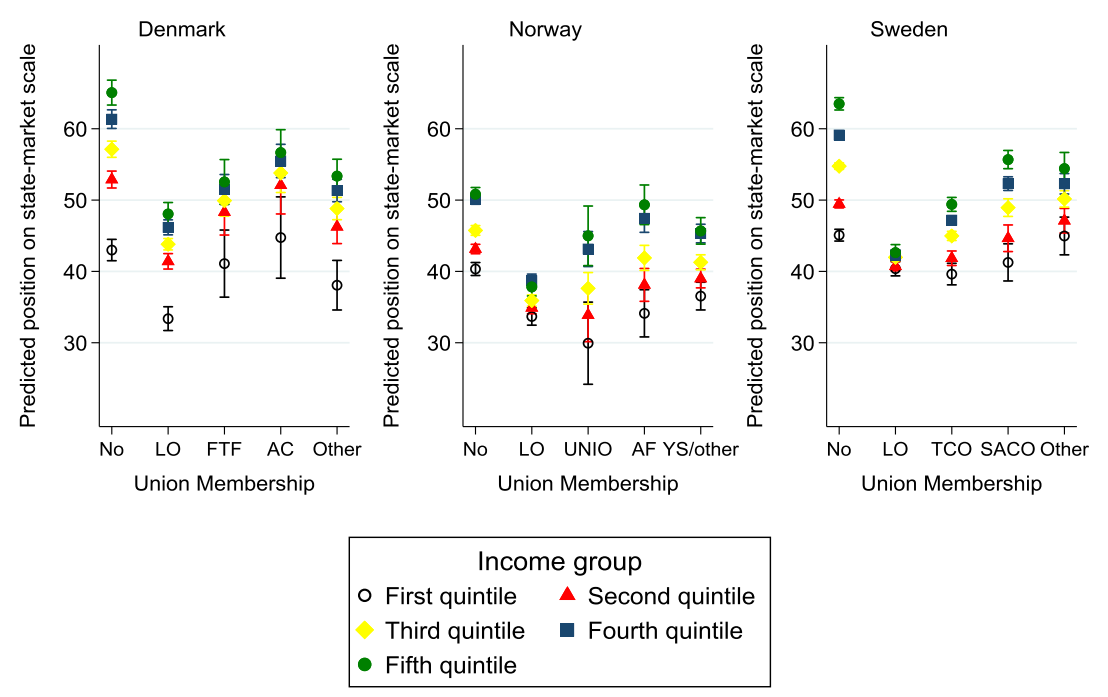


Note: Predicted values on the state-market scale from OLS regression models with fixed effects for survey years, Table A2. N=8055 (Denmark) 12,283 (Norway) 28,905 (Sweden) 


\section{Appendix}

Table A1: T-Tests of differences in means on selected issues across union federation membership

\begin{tabular}{|c|c|c|c|}
\hline Union contrast & $\begin{array}{l}\text { Redistribution of incomes has } \\
\text { gone far enough (scale from 1- } \\
\text { 3) }\end{array}$ & $\begin{array}{l}\text { More state control over } \\
\text { private investments/ } \\
\text { privatization (scale from 1-5) }\end{array}$ & State-market scale $(0-100)$ \\
\hline \multicolumn{4}{|l|}{ Denmark } \\
\hline Non-member vs. LO & $0.25(0.02)^{* *}$ & $0.19(0.02)^{* *}$ & $9.21(0.49)^{* *}$ \\
\hline FTF vs. LO & $0.06(0.03) \mathrm{ns}$ & $0.27(0.04)^{* *}$ & $2.22(0.86)^{* *}$ \\
\hline AC/Lederne vs. LO & $0.33(0.04)^{* *}$ & $0.48(0.05)^{* *}$ & $14.53(0.94)^{* *}$ \\
\hline AC/Lederne vs. FTF & $0.27(0.04)^{* *}$ & $0.21(0.06)^{* *}$ & $7.54(1.17)^{* *}$ \\
\hline \multirow{2}{*}{$\begin{array}{l}\text { AC/Lederne vs. } \\
\text { non-member }\end{array}$} & $0.07(0.04)^{*}$ & $0.29(0.05)^{* *}$ & $5.32(0.94)^{* *}$ \\
\hline & $\mathrm{N}=13,823$ & $\mathrm{~N}=13,976$ & $\mathrm{~N}=13,803$ \\
\hline \multicolumn{4}{|l|}{ Norway } \\
\hline Non-member vs. LO & $0.41(0.03)^{* *}$ & $0.42(0.03) * *$ & $10.64(0.43)^{* *}$ \\
\hline UNIO vs. LO & $0.53(0.07)^{* *}$ & $0.04(0.06) \mathrm{ns}$ & $5.98(1.04)^{* *}$ \\
\hline AF vs. LO & $0.58(0.06)^{* *}$ & $0.05(0.05) \mathrm{ns}$ & $8.87(0.82)^{* *}$ \\
\hline $\begin{array}{l}\text { AF vs. UNIO (after } \\
1997 \text { ) }\end{array}$ & $0.05(0.08)^{*}$ & $0.01(0.07) \mathrm{ns}$ & $2.88(1.22)^{*}$ \\
\hline AF vs. non-member & $0.16(0.06)^{* *}$ & $-0.37(0.05)^{* *}$ & $-1.78(0.77)^{*}$ \\
\hline \multirow[t]{2}{*}{ YS vs. LO } & $0.28(0.04)^{* *}$ & $0.14(0.04)^{* *}$ & $5.99(0.63)^{* *}$ \\
\hline & $\mathrm{N}=14,986$ & $\mathrm{~N}=16,377$ & $\mathrm{~N}=14,868$ \\
\hline \multicolumn{4}{|l|}{ Sweden } \\
\hline Non-member vs. LO & $0.55(0.03)^{* *}$ & $0.44(0.02)^{* *}$ & $13.10(0.31)^{* *}$ \\
\hline TCO vs. LO & $0.43(0.03)^{* *}$ & $0.27(0.02)^{* *}$ & $4.97(0.36)^{* *}$ \\
\hline SACO vs. LO & $0.90(0.05)^{* *}$ & $0.41(0.03) * *$ & $9.80(0.48)^{* *}$ \\
\hline SACO vs. TCO & $0.47(0.05)^{* *}$ & $0.14(0.03) * *$ & $4.83(0.50)^{* *}$ \\
\hline \multirow{2}{*}{$\begin{array}{l}\text { SACO vs. non- } \\
\text { member }\end{array}$} & $0.34(0.45)^{* *}$ & $-0.03(0.03)$ & $-3.30(0.46)^{* *}$ \\
\hline & $\mathrm{N}=10,431$ & $\mathrm{~N}=22,118$ & $\mathrm{~N}=34,622$ \\
\hline
\end{tabular}

Note: The values show T-tests of means for the first minus the second mentioned federation for all available years with valid answers. Positive values indicate that the first mentioned federation has more right-wing/pro-market attitudes than the second mentioned. $*<.05 * *<.01$ ns: not significant. 


\section{Data sources used}

\section{Denmark}

Valgundersøgelsen 1979, DDA-0287

Valgundersøgelsen 1981, DDA-0529

Valgundersøgelsen 1984, DDA-0772

Valgundersøgelsen 1987, DDA-1340

Valgundersøgelsen 1990, DDA-1564

Valgundersøgelsen 1994, DDA-2210

Valgundersøgelsen 1998, DDA-4189

Valgundersøgelsen 2001, DDA-12516

Valgundersøgelsen 2005, DDA-18184

Valgundersøgelsen 2007, DDA-26471

Valgundersøgelsen 2011, DDA-27067

\section{Norway}

Valgundersøkelsen 1981, NSD-0063

Valgundersøkelsen 1985, NSD-0064

Valgundersøkelsen 1989, NSD-0005

Valgundersøkelsen 1993, NSD-0166

Valgundersøkelsen 1997, NSD-0393

Valgundersøkelsen 2001, NSD-0663

Valgundersøkelsen 2005, NSD-0973

Valgundersøkelsen 2009, NSD-1487

Valgundersøkelsen 2013, NSD-2215

\section{Sweden}

Super Riks-SOM 1986-2012, SND-0905 (Weibull, Lennart, Sören Holmberg, Henrik Oscarsson, Johan Martinsson and Elias Markstedt. 2014. Super-Riks-SOM 1986-2012, v2014.1.2. Göteborgs Universitet: SOM-institutet,

www.som.gu.se.) 